\title{
Kalliopi Summer Pear
}

\author{
Thomas Sotiropoulos ${ }^{2}$ and Georgios Syrgianidis ${ }^{1}$ \\ Pomology Institute, National Agricultural Research Foundation (NAGREF), \\ R.R. Station 38, Naoussa, 59200, Greece
}

\section{Nikolaos Koutinas \\ Alexander Technological Educational Institute of Thessaloniki, Department of Crop Production, P.O. Box 141, Thessaloniki, 57400, Greece}

Antonios Petridis

School of Agriculture, Aristotle University of Thessaloniki, Thessaloniki, 54124, Greece

\section{Dimitrios Almaliotis \\ Soil Science Institute (NAGREF) P.O. Box 60435, Thermi-Thessaloniki, 57001 Greece}

Additional index words. cultivar description, fruit breeding, Pyrus communis

\begin{abstract}
'Kalliopi' is a mid- to late July maturing pear cultivar originating from a cross between the local Greek pear cultivars Kristali and Kontoula. Fruit are obtuse-pyriform to nearly turbinate with equatorial diameter $\approx 50 \mathrm{~mm}$, fruit length $\approx 45 \mathrm{~mm}$, and fruit weight $\approx 121 \mathrm{~g}$. Productivity of 'Kalliopi' was lower than 'Coscia'; however, yield efficiency of the two cultivars was not different. Total soluble solids and firmness of 'Kalliopi' were higher than 'Coscia', whereas total titratable acidity was not different among the cultivars. The flesh is yellow-white, juicy, sweet-flavorful, and fine-grained with very few stone cells (scleroids). The skin is green, blushed red with sun exposure, smooth, free of russeting, and has no tendency to become waxy in storage. Fruit ripens on the tree in mid- to late July, and a selective harvest of three picks is required. The fruit flavor is sweet. After harvest, fruits can be kept at room temperature for $\approx 1$ week or they can be refrigerated $\left(1{ }^{\circ} \mathrm{C}\right)$ for 1 month after which time internal breakdown tends to occur.
\end{abstract}

\section{Origin}

In Greece, the total pear production in 2007 was 75,249 $\mathrm{t}$ and acreage was 4,000 ha (FAO, 2007). The main pear cultivars grown in Greece are 'Kristali' and 'Williams'. 'Kontoula' summer cultivar is also popular, but its main disadvantage is its small fruit size ( $\approx 80 \mathrm{~g}$ ). Therefore, a marketing opportunity for new summer cultivars is high. The cultivar Kalliopi (the muse of epic poetry in Greek mythology) was derived from a cross between the Greek local pears (Pyrus communis L.) 'Kristali' and 'Kontoula' (seed parent) made

Received for publication 28 Aug. 2009. Accepted for publication 29 Aug. 2009.

${ }^{1}$ Current address: Kampiti 15, 59200 Naoussa, Greece.

${ }^{2}$ To whom reprint requests should be addressed; e-mail thosotir@otenet.gr. in 1967 at the Greek Pomology Institute by the researcher G. Syrgianidis, who also made the initial selection 6 years later. The evaluation and the description were done exclusively in the Greek Pomology Institute that is located in Naoussa (northern Greece, long. $22^{\circ} 12^{\prime} 0^{\prime \prime} \mathrm{E}$; lat. $40^{\circ} 29^{\prime} 04^{\prime \prime} \mathrm{N}$; elevation 225 $\mathrm{m})$. The mean maximum temperature of the experimental area is $38^{\circ} \mathrm{C}$ in July, whereas the mean minimum temperature is $-7{ }^{\circ} \mathrm{C}$ in January. Chilling requirement of the trees is low--medium and from our observations, 'Kalliopi' may be classified in the same group with the cultivar Beurre Anjou, whereas it has significant lower chilling requirement than 'Williams' and 'Beurre Hardy'. The objective of this research was to give information about the new pear cultivar Kalliopi.

\section{Description}

Tree. When scions were grafted on 'Provence' quince (BA 29; Cydonia oblonga Mill.) rootstock, trees were moderately vigorous with a fairly upright habit. Scaffold branch angle was $30^{\circ}$ to $45^{\circ}$ from vertical. Performance has not been tested on other rootstocks. Trees were grafted in situ and started producing fruit 3 to 4 years later. Maximum production was reached at the seventh year. Trees were trained as a central leader system. Trees set annual heavy crops unless there are unfavorable weather conditions during anthesis. When trees set heavy crops, thinning was necessary to improve fruit size and to avoid biennial bearing. Chemical thinners for pear include: 1-napthylacetic acid (NAA), its amide (NAAm), ethephon, conjugates of NAA and NAAm, and benzyladenine, but chemical thinning practices give quite unpredictable results (Wertheim, 2000). Chemical thinning trials were not accomplished for 'Kalliopi' pear and hand thinning is exclusively performed by growers by keeping one fruit per cluster, usually when the crops are heavy. Annual fruit production per tree of 'Kalliopi' grafted on BA 29 rootstock, over a period of 4 years (from the sixth until the ninth year of the trees), averaged $45 \mathrm{~kg}$. Productivity of 'Coscia' was higher than 'Kalliopi' (Table 1). However, yield efficiency of the two cultivars was not different. Yield efficiency of 'Kalliopi' $[\mathrm{kg} /$ tree to trunk cross-sectional area $\left.\left(\mathrm{cm}^{2}\right)\right]$ at the ninth year of the trees was 0.62. For the same age of the trees, yield efficiency of 'Kalliopi' was significantly lower than 'Williams' when grafted on the same rootstock (0.83) (Sotiropoulos, 2006). Bark color of 1- to 2-year-old shoots is gray-orange. Branch lenticels are oval, 0.5 to $0.7 \mathrm{~mm}$ in diameter, and gray-white. Vegetative buds are medium in size and oblique.

Leaves. The leaves are oval with an attenuate tip, $\approx 63 \mathrm{~mm}$ long and $\approx 46 \mathrm{~mm}$ wide. Leaf surfaces are smooth, the dorsal surface is shiny, and there is no pubescence. The petiole is yellow green and $\approx 33 \mathrm{~mm}$ long. Leaf fall occurs in late November.

Flowers. The trees require crosspollination. Flowering starts in the last week of March and has a good overlap with that of 'Williams', 'Highland', 'Conference', and 'Doyenne du Comice', although compatibility with these has not been tested. Known suitable pollenizers include the Greek local cultivars Vergina and Kristali (Syrgianidis, 1992). Flowers have white oval petals and pink anthers. Stamens are white, 4 to $5 \mathrm{~mm}$ long. The pistils are 5 to $6 \mathrm{~mm}$ in length, rounded, fused at the base, and they are at the same height as the stamens. The pollen is yellow.

Diseases. The trees are not tolerant to fire blight [Erwinia amylovora (Burr.) Winsl. et al.] (Syrgianidis, 1992). Research is needed to evaluate susceptibility to pear decline and other diseases.

Fruits. Fruit characteristics reported are mean values taken over 4 consecutive years from 2005 to 2008 . Fifteen fruit per tree from 30 trees at random in a planting of 320 trees were used to determine the means. Each sample was consisted of five fruits per tree for determination of the quality characteristics. Means were determined using SAS software (Version 9.1.3; SAS Institute, Cary, NC). Mixed buds are borne on 1-year-old shoots and spurs generally found on shoots at least 2 years old. Fruit are obtuse-pyriform to nearly turbinate with equatorial diameter $\approx 50 \mathrm{~mm}$, fruit length $\approx 45 \mathrm{~mm}$, and fruit weight $\approx 121 \mathrm{~g}$ (Fig. 1). Fruit weight and fruit length of 'Kalliopi' were lower than 'Coscia', whereas fruit diameter was not different among the cultivars (Table 1). The flesh is yellow-white, juicy, flavorful, aromatic, and with very few stone cells. The diameter of the core is $\approx 3 \mathrm{~mm}$. The skin is smooth, free of russeting, and has no tendency to become waxy in storage. The lenticels are inconspicuous. The pedicel of the fruit is fleshy, medium in length $(\approx 15 \mathrm{~mm})$, green-yellow, and oblique to the fruit axis with a petiole basin low in depth and width. Although the pedicel is quite fleshy, storage disorders of the pedicel were not detected. The calyx tends to be persistent, inconspicuous, and apressed to the pistillate end at maturity. 
Table 1. Productivity, yield efficiency, fruit weight, fruit equatorial diameter, and fruit length of the cultivars Kalliopi and Coscia over a period of 4 years.

\begin{tabular}{lccccc}
\hline Cultivar & $\begin{array}{c}\text { Productivity } \\
(\mathrm{kg} / \text { tree })\end{array}$ & $\begin{array}{c}\text { Yield efficiency }[\mathrm{kg} / \text { tree to } \\
\left.\text { trunk cross-sectional area }\left(\mathrm{cm}^{2}\right)\right]\end{array}$ & $\begin{array}{c}\text { Fruit } \\
\text { wt }(\mathrm{g})\end{array}$ & $\begin{array}{c}\text { Fruit diam } \\
(\mathrm{mm})\end{array}$ & $\begin{array}{c}\text { Fruit length } \\
(\mathrm{mm})\end{array}$ \\
\hline Kalliopi & $45.0 \mathrm{~b}^{\mathrm{z}}$ & $0.62 \mathrm{a}$ & $121 \mathrm{~b}$ & $50 \mathrm{a}$ & $45 \mathrm{~b}$ \\
Coscia & $51.5 \mathrm{a}$ & $0.66 \mathrm{a}$ & $139 \mathrm{a}$ & $54 \mathrm{a}$ & $80 \mathrm{a}$ \\
\hline
\end{tabular}

${ }^{\mathrm{z}}$ Means followed by the same letter in the same column are not significantly different (Duncan's multiple range test, $P \leq 0.05$ ).

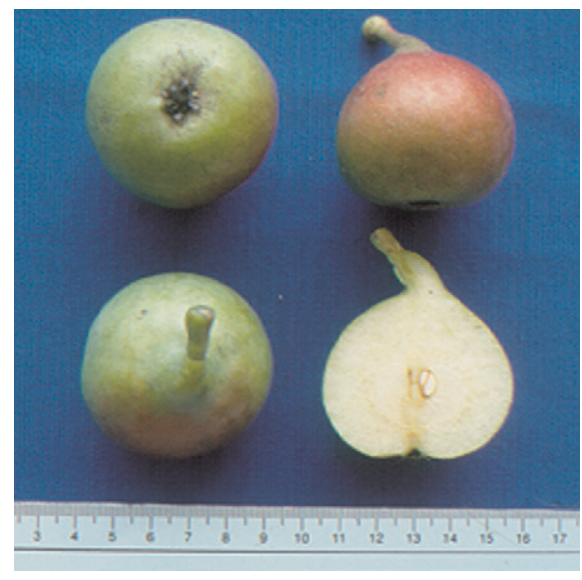

Fig. 1. Fruits of 'Kalliopi'.

Fruit mature on the tree in mid- to late July, coincident with 'Coscia' and 'Tosca', $10 \mathrm{~d}$ earlier than 'Santa Maria' and $\approx 40$ d earlier than 'Williams'. 'Kalliopi' can be considered as an alternative to 'Coscia', 'Tosca', and so on. Multiple harvests (up to three) are required under moderately cropped conditions. Thinning would take care of this problem. Harvest cost for three to four picks must be greater than thinning would be, particularly with a chemical thinner. Although fruits are small in size, the acceptance by the consumers is high in Greece as a result of the high quality and earliness. Fruits are used exclusively for fresh market. Until now, there was no potential for export because the quantities produced are small and cover only the local market. Approximately 130 ha are cultivated mainly in northern Greece with an average annual production of $2500 \mathrm{t}$. When harvested, the skin is green with red blush where exposed to sunlight. Fruits look like the fruits of its parent 'Kontoula', but they are larger in size, have fewer stone cells, and have better eating quality. With regard to harvest maturity indices, the most common used are the total soluble solids content and the change of ground color from green to light yellow. Fully mature fruit of the cultivars Kalliopi and Coscia were evaluated solids (measured with the Atago PR-1 electronic refractometer; Atago Co. Ltd., Tokyo, Japan), firmness (measured with an Effegi penetrometer $8 \mathrm{~mm}$ tip; Effegi, Milan, Italy), ascorbic acid content (measured by oxalic total antioxidant capacity as described by immediately after harvest. Total soluble acid $1 \%$ ), total titratable acidity, and

Table 2. Total soluble solids, firmness, ascorbic acid, total titratable acidity, and total antioxidant capacity of the cultivars Kalliopi and Coscia over a period of 4 years.

\begin{tabular}{lccccc}
\hline Cultivar & $\begin{array}{c}\text { Total soluble } \\
\text { solids }(\%)\end{array}$ & $\begin{array}{c}\text { Firmness } \\
\left(\mathrm{kg} \cdot \mathrm{cm}^{-2}\right)\end{array}$ & $\begin{array}{c}\text { Ascorbic acid } \\
\left(\mathrm{mg} \cdot \mathrm{g}^{-1} \text { fresh wt }\right)\end{array}$ & $\begin{array}{c}\text { Total titratable } \\
\text { acidity }(\%)\end{array}$ & $\begin{array}{c}\text { Total antioxidant } \\
\text { capacity }(\mu \mathrm{M})\end{array}$ \\
\hline Kalliopi & $14.50 \mathrm{a}^{\mathrm{z}}$ & $4.85 \mathrm{a}$ & 0.114 & $0.93 \mathrm{a}$ & 11 \\
Coscia & $11.92 \mathrm{~b}$ & $4.60 \mathrm{~b}$ & - & $0.91 \mathrm{a}$ & - \\
\hline
\end{tabular}

${ }^{\mathrm{z}}$ Means followed by the same letter in the same column are not significantly different (Duncan's multiple range test, $P \leq 0.05$ ).

Koukourikou-Petridou et al. (2007) are reported in Table 2. Total soluble solids and firmness of 'Kalliopi' were higher than 'Coscia', whereas total titratable acidity was not different among the cultivars. After harvest, fruits can be kept at room temperature for $\approx 1$ week or they can be refrigerated in common rooms (air, $1{ }^{\circ} \mathrm{C}$ ) for 1 month (Syrgianidis, 1992). After 1 week without refrigerated storage, fruits exhibit flesh breakdown.

In conclusion, 'Kalliopi' is a promising summer pear cultivar. Its cultivation is expanding from year to year in Greece as a result of its high quality and earliness that are accepted by the consumers.

\section{Availability}

'Kalliopi' pear has been registered in the official list of the Greek Ministry of Agriculture and is presently available in small amounts from the Greek Pomology Institute (P.O. Box 122, 59200, Naoussa, Greece). A few trees are kept in a screenhouse and are virus-free. The cultivar is currently distributed from several private nurseries in northern Greece without patent or license protection. We have not yet applied for a protection according to UPOV (International Union for the Protection of New Varieties of Plants) guidelines.

\section{Literature Cited}

FAO. 28 Aug. 2009. <http://www.fao.org>.

Koukourikou-Petridou, M., D. Voyatzis, D. Stylianidis, T. Sotiropoulos, and I. Therios. 2007. Effects of some growth regulators on pre and after storage quality of Red Chief Delicious apples. Eur. J. Hort. Sci. 72:8-11.

Sotiropoulos, T.E. 2006. Performance of the pear cultivar Williams Bon Chretien grafted on seven rootstocks. Aust. J. Exp. Agr. 46:701705.

Syrgianidis, G. 1992. New pear cultivars. Agr. Tech. 3:61-63 [in Greek].

Wertheim, S.J. 2000. Developments in the chemical thinning of apple and pear. Plant Growth Regulat. 31:85-100. 